\title{
First results in modelling objective well-being in Hungary at lower territorial level*
}

\begin{abstract}
Developing complex indicators measuring economic output, added value and indicators relying on an entirely different basis, researchers worked on the assumption that economic output does not correlate strongly with people's happiness or quality of life. Most measurements relate to countries and federal states. Only a few seek to present or model differences at lower territorial levels. This study discloses the first results of pilot calculations that have been performed as part of Hungary's Social Renewal Programme. These explore differences at the level of Hungarian districts (LAU1) with the proviso, that the spatial structure presented only reflects what is called objective well-being. A more comprehensive picture can be obtained only if the subjective well-being dimensions incorporating and weighted by the results of a large-scale sample survey, conducted in the meantime, are also taken into account.
\end{abstract}

Keywords: well-being, spatial structure, model-calculation, weighting process, districts.

\section{Preface}

Developing complex indicators measuring economic output and added value (HDI, UNDP Millennium Development Goals), and indicators relying on an entirely different basis (the National Happiness Index and well-being indexes with various content) (see e.g. Constanza 2009, Diener-Biswas-Diener 2002, Booysen 2002, Beyond GDP 2009, Stieglitz 2009, Atlas... - The World Bank 2013, CIW 2012, Kovacevic 2010, Marks et al. 2006), researchers worked on the assumption that economic output does not correlate strongly with people's happiness or quality of life. Most measurements relate to countries and federal states. Only a few seek to present or model differences at lower territorial levels (see e.g. CIW 2009, OECD 2011, Boelhouwer-Stoop 1999, Diefenbacher-Zieschank 2008, Blanchflower-Oswald 2004, NEF 2012, and based on the example of Nottingham, NEF 2004).

a) Senior Research Fellow, Hungarian Academy of Sciences Centre for Economic and Regional Studies, Békéscsaba Department. H-5600 Békéscsaba, Szabó D. u. 40-42., Hungary. E-mail: nagyg@rkk.hu

b) Research Fellow, Hungarian Academy of Sciences Centre for Economic and Regional Studies Central and Northern Hungarian Department, H-1112 Budapest, Budaörsi út 45., Hungary. E-mail: koosb@rkk.hu

* Social Conflicts - Social Well-being and Security - Competitiveness and Social Progress. The development of the model was part of the research conducted under project no. TÁMOP (Social Renewal Operational Programme)-4.2.2.A-11/1/KONV2012-0069. Supervisor: Viktória Szirmai. professor of HAS. 
In recent years, there have been similar research projects involving new methods for measuring the changing spatial structure of Hungary from the viewpoint of innovation potential (Bajmócy-Lengyel-Málovics (eds.) 2012, Gébert-Málovics-Fáskerti 2012). Alternatively, following on from an extensive range of published research, complex indexes imported from another post-soviet country (the Latvian Territory Development Index, used by Németh-Verce-Dövényi 2014), have been applied. In this case, the standard approach was to sidestep the GDP/capita based regional differences.

This study discloses the first results of pilot calculations that have been performed as part of Hungary's Social Renewal Programme (TÁMOP), which explores differences at the level of Hungarian districts (LAU1). It carries the proviso that the spatial structure presented reflects what is called objective well-being. A more comprehensive picture can be obtained only if the subjective well-being dimensions incorporating and weighted by the results of a large-scale sample survey, conducted in the meantime, are also taken into account.

\section{The Stiglitz-Sen-Fitoussi Report}

In February 2008, the then French President, Nicholas Sarkozy, who was highly unsatisfied with the amount of reality the content of statistical information on economic growth and societal development reflected, mandated Joseph Stiglitz (chair), Amartya Sen (adviser) and Jean-Paul Fitoussi (co-ordinator) to establish a committee that later came to be known as "Committee on the Measurement of Economic Performance and Social Progress". The purpose of establishing such a committee was to assess the limits of GDP as an indicator of economic performance and social progress, including the issues associated with such assessment. Also, to identify further information that might be needed for indicators betterreflecting social progress, and analyse and discuss the reliability of alternative assessment methods (Stieglitz-Sen-Fitoussi 2009).

The report differentiates between current well-being and sustainable well-being, i.e. whether this can last over time. Current well-being relates to both economic resources, such as income, and with non-economic aspects of peoples' life (what they do and what they can do, how they feel, and the natural environment they live in). Whether these levels of well-being can be sustained over time depends on whether stocks of capital that matter for our lives (natural, physical, human, social) are passed on to future generations.

Another key message and unifying theme of the report is that the time is ripe for our measurement system to shift the emphasis from measuring economic production to measuring people's well-being. Emphasising well-being is important because there appears to be an increasing gap between the information contained in aggregate GDP data and what counts for "common people's well-being".

The three authors put forward 11 recommendations for a new measurement methodology, according to which, the following areas (dimensions) should be considered simultaneously:

I. Material living standards (income, consumption and wealth);

II. Health;

III. Education;

IV. Personal activities including work; 
V. Political voice and governance;

VI. Social and personal connections and relationships;

VII. Environment (present and future conditions);

VIII. Insecurity, of an economic as well as a physical nature.

\section{A system of indicators and a methodology for model-based measurements in Hungary}

In designing the model, the authors relied on the recommendations in the Stiglitz-SenFitoussi Report as a starting point. Although we strove to bear the recommendations in mind in engineering a Hungarian indicator of well-being, we faced a severe shortage of information in a number of areas, including environmental sustainability, material wellbeing and the household perspective. Such data are, as a rule, available at a national or even a regional level, but not at lower levels including settlements, small regions, districts and urban agglomerations.

Aware of this, in determining well-being factors, we assigned the indicators used into two categories. The core component of a well-being indicator is the fundamental data that can be easily generated from the data regularly supplied by the Hungarian Central Statistical Office (e.g. 2011 census data and the HCSO's System of Territorial Statistical Data from 2011 ). Another class of variables includes auxiliary or ad hoc indicators whose data requirements can be satisfied only by targeted data collection. Thus, the repeat determination of the value of such indicators and the capture of changes over time requires a rather expensive repeated collection of data.

The underlying reasons for such separation of the indicators used are as follows:

- The calculation of a well-being indicator by means of basis indicators does not require a time-consuming and costly collection of data by researchers. The data requirements for a well-being indicator, thus calculated, can be satisfied. Its value can be established over a broad time horizon, i.e. for earlier dates. It follows that such an indicator is also suitable for capturing processes as they evolve over time.

- Indicators based on data collected by researchers themselves help follow the recommendations in the SSF Report; however, due to their specific nature, they are not valid for earlier dates, and their validity for future dates depends fundamentally on external factors (i.e. whether there are data sources available for repeated data collection).

- Separating basis indicators from ad hoc ones enables us to analyse the degree to which variables calculated from target data modify the value of well-being indicators calculated from basis indicators. As a result, proxy variables adequately similar to the indicators that are hard to determine, owing to their data requirements, can be delineated.

- In order that areas that need to be included can be captured, the starting point for designing the dimensions of well-being were the recommendations of the Stiglitz Report (2009). In addition, also included were the dimensions (variables) of the models that we thought bore relevance on the basis of our review of international literature. The benchmarks considered were the Canadian Index of Well-Being (CIW 2009), Wachstum, Wohlstand, Lebensqualität (WWL 2013), and OECD's 
Your Better Life Index (OECD BLI 2011 and 2013). The models found to be of relevance exhibited strong similarities in terms of the dimensions studied, which is attested to by the fact that income, employment, education, qualification, environmental characteristics, democratic values, participation and healthcare feature in all models. Furthermore, there are also other shared dimensions, which emerge in at least in three models. They are housing, socialising (social and community-level connections), public security and leisure.

- We complemented shared well-being dimensions with two specific areas that are likely to affect well-being in Hungary. These are the availability of public services and the sustainability of local demography. These two dimensions were included to capture the issues specific to Hungarian settlements and the small villages in their vicinity as they are fundamental determinants of the quality of life, well-being and future of local residents.

- Government and municipality debt was intentionally left out. Although including the sustainability of government/municipality operation in the model could be a major component, a recent remodelling in Hungary (rearrangement of the tasks of municipalities and the resultant transformation of funding) has rendered the analysis of historical data meaningless. That notwithstanding, facilitating a Hungarian well-being model to include this area in some way is a key future challenge.

\section{Determination of an objective well-being model}

The well-being dimensions and variables surveyed enable us to describe objective wellbeing by using one value for each, and to generate one single well-being index value based on the values of these dimensions. In determining the value of the well-being index, the aim was to rank the territorial unit in question with a national (average) ranking. Although a well-being index determined in this manner is suitable for keeping track of changes over time, it is not for international comparison.

In determining a composite well-being index, we first stabilised (standardised) variables by using standard deviation measured at the appropriate territorial level (i.e. at the level of settlements, small regions, districts, urban agglomerations, counties and regions) and the national value (serving as mean value):

$$
Z=\frac{x-\mu}{\sigma}
$$

where $\mathrm{x}$ is the value to be stabilised (standardised), $\sigma$ is standard deviation and $\mu$ is an expected value (mean value).

A standardised variable with a high value just means that it significantly differs from the average. Whether this affects objective well-being favourably or unfavourably cannot be established. In order to enable it to do so, we need to interpret values, i.e. assign a direction to the values of standardised variables, so as to ensure that a negative value reflects - for all 30 variables - a level of well-being level that is lower than the national one; conversely, a positive value indicates a better-than-national level of well-being. ${ }^{1}$

1 Technically speaking, identical direction means a change in the signs of the variables concerned. 
Constructing these well-being dimensions indices for Hungary, we can calculate one complex well-being indicator, which contains the relative position of subjects in different areas of well-being. It is possible to characterize a spatial unit with only one number, but only by losing a high proportion of information, as a favourable position in one well-being dimension should be counterbalanced by a poor situation in another. This is why this method is very useful to identify the extreme valued territorial units, with the best or worst position in most well-being dimensions.

After we calculate the values of certain dimensions, we have to find a 'suitable' weight to create one complex index of well-being. Choosing the proper weight is one of the most important steps of the calculation, as it defines the conversion rate among dimensions (for example: what rate of increase in income would counterbalance higher levels of uncertainty in a family's existence?) In practice, most calculations neglected the weighting; they give equal importance to all well-being dimensions. If there is any kind of weighting, three primary methods can be used (see: Decancq-Lugo 2010): the experts' opinion, based on interviews, statistical data concentration methods (e.g. principal component analysis), or questionnaire-based weight. In our research, we have the results of a 2000 panel, representing age, sex, education and settlement types of Hungary. This allows the calculation of a weighted model of well-being indicators (Table 1.) based on the population's opinion of the relative importance of such dimensions.

In the process, we re-calculate the objective well-being index using the median value, instead of simple average, as in three of the ten dimensions, the individual opinions were highly heterogeneous in the areas of education, work and safety. (i.e. the quality of education was quite unimportant for elderly people, but one of the most important factors for students and their parents.) Hungarians who replied to the questionnaire feel employment, and health and safety are the most important fields, followed by incomes and housing. All the other dimensions, such as education, politics, environment, demographic factors and accessibility of public services seemed to get less weight in our model calculation.

The results of principal component analysis suggest that all the ten dimensions cannot merge into one index. It is important to see in this calculation, that the goal was not presenting the variables the variables with low level communalities, but to identify all the spatial units with favourable or less favourable positions in the majority of the well-being dimensions. According to all these points, we calculated the scores of certain dimensions with the weights obtained from the questionnaire and created the transformed objective well-being index. 
Results of the weighting process and principal component analysis, using the Decancq-Lugo-method

\begin{tabular}{l|c|r|r|r|r|r|r|r|r|r}
\hline & $\begin{array}{c}\text { Employ- } \\
\text { ment } \\
\text { (Perso- } \\
\text { nal } \\
\text { active- } \\
\text { ties) }\end{array}$ & Health & $\begin{array}{c}\text { Safety } \\
\text { (In- } \\
\text { security) }\end{array}$ & Income & Housing & $\begin{array}{c}\text { Educa- } \\
\text { tion }\end{array}$ & $\begin{array}{c}\text { Political } \\
\text { partici- } \\
\text { pation }\end{array}$ & $\begin{array}{c}\text { Environ- } \\
\text { ment }\end{array}$ & $\begin{array}{c}\text { Access } \\
\text { to basic } \\
\text { public } \\
\text { services }\end{array}$ & $\begin{array}{c}\text { Demog- } \\
\text { raphy }\end{array}$ \\
\hline $\begin{array}{l}\text { Questionnaire } \\
\text { based weight }\end{array}$ & 1.15 & 1.15 & 1.15 & 1.03 & 1.03 & 0.92 & 0.92 & 0.92 & 0.92 & 0.8 \\
$\begin{array}{l}\text { Equally } \\
\text { weighted }\end{array}$ & 1 & 1 & 1 & 1 & 1 & 1 & 1 & 1 & 1 & 1 \\
$\begin{array}{l}\text { Principal } \\
\text { component } \\
\text { analysis }\end{array}$ & 0.84 & 0.48 & 0.17 & 0.85 & 0.83 & 0.87 & -0.21 & 0.49 & 0.5 & 0.48 \\
Communalities & 0.763 & 0.384 & 0.025 & 0.619 & 0.763 & 0.814 & 0.003 & 0.422 & 0.208 & 0.421
\end{tabular}

Source: own calculation.

\section{The first results of calculations at actual LAU1 (district) level}

While calculating, for example, the index of objective well-being or any other territorial values, we noticed that the difference between extreme values grew as we moved from larger territorial units towards a lower level of aggregation. However, what is truly surprising is that there is a higher concentration of increased deviation mainly in the negative domain, i.e. districts with a lower well-being index are greater in number. Nevertheless, county and regional averages can counterbalance such lower indexes effectively because the number of the population in districts is lower than in county seats and regional centres.

We use the differences identified on map charts to analyse differences at a district level. Our analysis focuses on internal territorial inequalities at a LAU1 level, and compares the differences between the weighted and unweighted values of the objective well-being model. The results of the analyses use the traditional categories "developed-undeveloped" and "backward-advanced", the interpretation of which is restricted to the level of small regions.

The traditional spatial structure of Bács-Kiskun County is characterised by a bipolar structure, with Kecskemét at one end and Baja at the other, as well as the stable position of the cities and towns in the Kiskun area. Surprisingly, only Kecskemét and its environs are above the national average according to the objective well-being model. The values for Baja and its environs are similar to those for the Kiskőrös, Kalocsa, Kiskunfélegyháza average. Kiskunhalas is at a level one mark lower, at the level of Tiszakécske, Kiskunmajsa and Kunszentmárton, at least according to the basic model. (A relatively high value of the index for Kunszentmiklós is also attributable to the indirect appeal of the capital city due to its proximity.) The income weighting rearranges spatial structure only inasmuch as the edge of Kecskemét, over other places in the county, continues to become more distinct, a trend that is realistic over the longer term in light of a Mercedes-Benz capital project and the related development projects. The latter only seem to be targeting Kiskunfélegyháza 
(along the M5 motorway), however, the overweighting by questionnaire results reduced the value of the well-being index $(-0.3)$. What is surprising, is that the overweighting by questionnaire results reduces the well-being index of the Kiskörös district, also dubbed "the golden triangle". The likely cause of this is that the untaxed income of the 1980's and 1990's narrowed to a trickle in response to the global crisis. There are substantial absolute differences between the lowest and the highest well-being indexes of the county. They are around 11 points in both cases.

Concerning Békés County, based on social and economic indicators, besides Békéscsaba (the county seat), Gyula, Orosháza and Szarvas rank relatively higher. The economically most disadvantaged areas are South Békés County (Mezőkovácsháza) and North Békés County (Sarkad). Objective well-being indicators also corroborate the favourable ranking of Békéscsaba $(-0.08$ and -0.00$)$ and Gyula $(-0.58$ and -0.60$)$. The well-being index for Szarvas is more favourable than that of the Orosháza district despite the fact that more significant industrial organisations have survived and been set on a new development trajectory in the latter. The differentiation that has occurred over the past decade in the traditionally backward regions is also reflected in their economic and social indicators. Absolute differences were similar to those in Bács-Kiskun County: an overweighted indicator slightly improved the indicator of the county seat's environs and moderately upgraded Szarvas and Orosháza. It resulted in the worst indicators for the diverging regions.

In Csongrád County, as had been expected, five cities and their environs ${ }^{2}$ formed a series according to their size and level of development. Compared with this, indicators for the Kistelek and Mórahalom districts, once part of the farmstead area of Szeged, were considerably lower. Major well-thought out development, mainly in Mórahalom, over the past two decades coincided with a cycle of suburbanisation in the county seat. Development in Kistelek was facilitated by the construction and putting into service in 2003 of the M5 motorway and suburbanisation in Szeged. With the exception of Szeged district, what is striking about Csongrád County, relative to the other undeveloped counties, is that the weighting process hardly affects well-being indexes, i.e. labour market and income position are roughly in line with other indicators. Szeged, Hódmezővásárhely and Szentes ranked according to our calculation as they had ranked previously. Both Mórahalom and Csongrád fared better than Makó's environs, even on the basis of the model applying an economic weight. Although absolute differences were substantial (11 points), this followed from the favourable position of the regional centre and its environs rather than the deficiencies of Kistelek district with the highest well-being deficit. In the Southern Great Plain, according to the traditional order of development, Hódmezővásárhely ranks lower than Baja among the second-tier cities, based on the 'traditional' development rankings. However, when considering the well-being index, the town, along with Gyula, ranks $4^{\text {th }}-5^{\text {th }}$ just behind the county seats.

The traditional structure of space and slope development in Hajdú-Bihar County is similar to those in Csongrád County, insomuch, as Debrecen and its environs standout from the other regions in the county. We found that, regarding medium-sized cities, only Hajdúszoboszló has relatively good indicators. The objective well-being indicator also 
reflects this order: Debrecen with its well above the national value ranks first (although it falls behind Szeged). Hajdúszoboszló is roughly similar to Szarvas. The main engine of the local economy is tourism, and the overweighting by questionnaire results again slightly reduces the value of the well-being index in this city. Diverging spaces, such as Derecske and Hajdúhadház, and their respective environs, negatively stand out in terms of their wellbeing indexes. Indicators for the Berettyóújfalu and the Püspökladány districts are hardly any better. The application of the weighting leads to a lower well-being indicator for the majority of the districts in the county. Absolute differences are significant (11 points) similar to the former counties.

The spatial structure of Jász-Nagykun-Szolnok County is fundamentally affected by its distance from and the accessibility of Budapest. The excellent transport geography of Szolnok and its role as a county seat combined to achieve a favourable well-being index and an increase in the index during income weighting. Szolnok is in a better situation than Békéscsaba and Kecskemét, though the difference is not striking. Although the well-being index of the Jászság part of the county, attached to a wider catchment area of the capital city with numerous ties, is favourable within the county, it falls behind the national average considerably. Its favourable geographical location is reflected when the weighting is applied, because the value of the index increases in the second model calculation. The weighting leads to a further significant lowering of an already low well-being indicator in the Trans-Tisza districts of the county. No significant changes were observed in ranking relative to the traditional indicators of inequality. Kunhegyes, a core area of the inner periphery of the Central Tisza Region, exhibited the highest well-being deficit in the county; however, the situation in the other districts is hardly any better. Nevertheless, absolute differences are over 12 points higher than in the other counties in the Great Plain, as a consequence of the lower indicator for the county seat district and worse situation in spaces with well-being deficits.

The sharpest territorial differences were identified in Szabolcs-Szatmár-Bereg County in terms of its objective well-being indicator. The dichotomy between the county seat and the county is nearly as wide as between the capital city and the rural areas. The value of the indicator for the Nyíregyháza district is roughly the same as the one for Békéscsaba (and slightly lower than the one for Kecskemét with a similar population); however, if added, the weight reduces the value of the index significantly $(-0.4)$, which is quite an exception among county seats. The other districts of the county trail Nyíregyháza to an extreme degree.

The Mátészalka district, fairing relatively well in terms of its traditional indicators, was found to be outright poor as far as its well-being indicator was concerned (-9). Kisvárda, the other city representing major attraction fared slightly better $(-7)$, however, it only managed to rank second under the model where questionnaire results were weighted. Under the basic model, it was preceded by the Ibrány district, which is one of the most disadvantaged spaces within the county according to all traditional rankings for measuring development. What sets the county apart from other counties in Hungary is that weighting reduces the value of the well-being indicator for all regions to a dramatic extent (over 0.4 ). The absolute difference within the county is essentially the same as the average for other counties in the Great Plain. 
In Baranya County, with the exception of the Pécs district, the well-being index was negative for all regions, with values suggesting well-being far below the national average. Sellye and its LAU1 region ranked last in Hungary; the Hegyhát, Szigetvár and Szentlőrinc Regions fared somewhat better. Weighting slightly changed the value of the indexes in most cases (a modest increase for the Pécsvárad, Mohács, Bóly districts) suggesting employment, health and security imbalances. A difference of nearly 16 points between the most and the least economically advantaged regions indicates strong spatial divisions within the county.

In Somogy County, it is not the county seat where the well-being value is the highest (exceeding the national level), rather, in the environs of Siófok, which is a secondary centre in the county. The districts along the Lake Balaton (Fonyód, Siófok) and the county seat offer better living conditions; however, this did not seem to have exerted any impact on the Marcali, or Tab districts $(-6,-10$ points). More distant areas, with a few exceptions, ranked similar to the latter group in terms of their well-being indicators. The weighting process in some cases lowered indicators or did not improve them significantly.

In Tolna County, even the relatively advantaged Szekszárd district had well-being values below the national average. Under the weighted model, Paks and its environs had a relatively better position. Here, the employment dimension improves the index spectacularly. By contrast, it did not affect the county seat's well-being indicator at all. Although the Tamási district, a periphery in the county's ranking, had an extremely low well-being indicator, especially under the equally weighted model, it fared much better than did the most disadvantaged regions in Somogy and Baranya Counties. The overall differences are far below that in Baranya, Somogy, or the counties of the Great Plain.

Borsod-Abaúj-Zemplén County is one of the Hungarian counties where the well-being index was below the national average in all its districts; even the index for the regional centre was 1.5 points lower. It is here and not in Szabolcs County that three districts with the highest well-being deficits were identified among the country's last five: Cigánd, Gönc, Encs; however, Mezőcsát, Szikszó, Putnok are also in the last 15! Thus, Borsod seems a NUTS3 region with the highest absolute well-being deficit in Hungary. Relative to the county's general position, Miskolc's and Tiszaújváros's LAU1 units (TVK and Jabil Circuit) had favourable well-being indicators. There were only two districts where the weighting process improves the index moderately (Mezökövesd and Tokaj). By contrast, we identified three districts where weighting reduces an already low well-being factor by 0.3 points. Although absolute differences are not extremely high (12 points), the negative well-being values of the county seat make internal differences look less severe than they are in reality.

The traditional spatial structure of Heves County can be characterised by a favourable situation in Eger, Gyöngyös and Hatvan, and backwardness in the southeastern and northern peripheries. Our well-being model corroborated this territorial divide. Similar to Szeged, Eger's environs is one of the most advantaged small regions in East Hungary, although weighting led to a lower value of the index as in Szeged. Gyöngyös's secondary role is clearly substantiated by the fact that its level of well-being is only slightly lower than the national average and is somewhat improved by the weighting process. Accordingly, it is only one level lower than county seats. Relative to the population of the county seat, Hatvan has an outrightly favourable well-being indicator, especially under the 
model with a weighting $(-1.46)$, that is similar to Paks's corresponding indicator. It is relatively safe to say, that in the case of Hatvan, and to a lesser extent, Gyöngyös, the relative proximity of and easy access to the capital city exert a favourable impact on trends in the index. Absolute differences were high in the county (13 points). Trends were influenced by a positive indicator - well above the national average - the LAU1 unit of the county seat.

Nógrád County is another county where the objective well-being index had no positive value at a regional level. The bipolar character of the county (with Balassagyarmat, the former county seat at one end and Salgótarján, the current centre at the other) is also reflected in our models: Although the Balassagyarmat district has a slightly better indicator, compared with the county seat, the value of its well-being indicator is extremely low (3.16 and -2.86). What is specific to the spatial structure of Nógrád County is that the districts of the small towns Pásztó, and Bátonyterenye, rank not too far behind the county seat. Even Rétság district has a slightly better level of well-being comparing to Balassagyarmat. The application of the weighting increases the index of these districts (except Szécsény), suggesting a weak local economy, and hence, an unfavourable labour market situation. Although, spatial inequalities are moderate in the inner areas: the difference between the highest and the lowest value under the basic and the weighted model is around five. Unlike Bács-Kiskun and Heves Counties, where the impact of the capital city could be assumed, this county did not seem to benefit from such influence, partly because access to the county is difficult.

What we could not avoid noticing that the well-being indicators in Fejér County were places with values above, or close to the national average: in Székesfehérvár, the county seat; Dunaújváros, the secondary centre; Gárdony, a major tourist destination; Mór, undergoing re-industrialisation and Bicske, becoming a logistics centre. Based on the relevant data, the well-being indicator of the latter three rank only slightly lower than that of the regional centre with a population of 100,000 , and is significantly higher than Dunaújváros, a traditional industrial centre. Another notable feature of Fejér County is that - at least in comparison with the counties in South and East Hungary, with the exception of Mór - weighting generally raises the value of the objective well-being indicator even in regions with a well-being deficit (Polgárdi, Enying and Sárbogárd). These clearly delineable units, with a minor well-being deficit in the national comparison, are a manageable problem, in terms of both their number and population. Absolute differences are also not conspicuous (11 points), and more attributable to high well-being values in more advantaged districts than the indexes of those diverging.

With reagrd to the ratio of LAU1 units with a favourable well-being factor, to those with an unfavourable one, Komárom-Esztergom County is in an even more advantaged situation than Fejér County. Except for the Kisbér district, which is in effect, not in the lowest quartile in a national comparison, no disadvantaged space can be identified. A typical phenomenon is that, compared with Miskolc, the Oroszlány district, also long considered an area of industrial depression, had a higher indicator, especially when the weighting is applied. Spatial inequalities calculated on the basis of traditional indicators are usually moderate, and owing to a reliable urban structure, there are a number of advantaged areas in the county. This is also reflected in well-being indicators: the Komárom, Tata and Esztergom units have higher indicators than the county seat. The 
weighting process improves the indexes of all regions, and in some cases, to a marked extent. This is clearly attributable to a favourable economic structure and related good labour market opportunities. Absolute differences are very low (around 7.5 points) suggesting more moderate territorial inequalities in the county.

The spatial structure of Veszprém County is profoundly affected by Lake Balaton. Regarding traditional income and social indicators, the county's general indicators measuring development were improved by the advantaged position of the county seat and the areas along the lakeshore. Under the well-being model, the Veszprém, Balatonalmádi and Balatonfüred districts are well above the national average. Only in the Sümeg and Devecser districts, the traditional peripheries of the county, did we identify low and very low well-being indicators. The limitations of the Balaton phenomenon is confirmed by the fact that the well-being index of the Ajka and Zirc units, and to a lesser extent, even the Várpalota and Pápa districts are higher than that of Tapolca's values. Although, the Ajka and Várpalota LAU1 units were areas of industrial depression, they are affected by larger poles capable of development; the Zirc and Pápa districts should be able to boost their large surroundings with its numerous small villages. The weighting process also improved indexes throughout the county. Absolute differences are significant (approx. 13 points); however, this is due to Veszprém's outstandingly high well-being index (the highest in the Central Transdanubian Region) rather than the relatively low value for the Devecser unit.

The traditional spatial structure of Györ-Moson-Sopron County is tripolar. Indicators for Györ, Sopron and Mosonmagyaróvár, are high, while other districts are in a less advantaged situation. Under the objective well-being model, the above three cities and their environs fare well (Györ has the highest well-being indicator in the provinces in general, Sopron the third). Indicators for the Kapuvár and Csorna districts are also above the national average. Even the Tét and Pannonhalma units on the southern periphery barely fall behind. Overall, the weighting process boosted well-being indicators markedly (with the exception of Györ, where there had been some decline). Absolute differences are moderate in the county, barely exceeding 6 points, suggesting inner inequalities are even fewer than those in Komárom-Esztergom. In other words, the dominant features of the urban structure can - through their attraction - mitigate territorial inequalities in the county.

Objective well-being indicators are high for most of Vas County. Indicators for the traditional peripheries (particularly the Vasvár district) modify this rosy picture, however. Szombathely has the highest indicators comparable with Györ, Sopron and Veszprém. It is followed by five regions with indexes slightly above or below the national average. It should be noted that the Szentgotthárd unit, the automobile hub, ranks rather low (which, we think, is attributable to a special settlement structure in the Örség). Calculations showed that Köszeg, which did not fare well in the economic transformation, had higher values. The weighting process increased the well-being indicators in all LAU1 units, in some cases over 0.6 points. Absolute differences are relatively large (12 points), which is mainly due to the favourable situation in Szombathely and its environs, rather than a particularly disadvantaged Vasvár district.

Of the three West Transdanubian Counties, Zala County has the 'least impressive' economic and social indicators. Although it has three traditional centres (Zalaegerszeg, Nagykanizsa and the conurbation of Keszthely and Hévíz), they do not seem to be able to 
boost their surroundings as was the case in Györ-Moson-Sopron. Concerning the objective well-being indicator, of the three poles, only Keszthely and its environs are the most advantaged, on a par with, for instance, Komárom. We measured barely higher well-being indicators for the Keszthely LAU 1 unit compared to the Zalaegerszeg district. The difference is wider under the standard model, compared to the weighted one. Further strengthened by weighting, the indicator for Nagykanizsa and its environs falls somewhat behind the national average. Of the regions with small towns as their centres, Lenti had outright favourable indicators $(-1.53$ and -0.97$)$. By contrast, although their indicators were similar, the Letenye and Zalaszentgrót districts fell considerably behind, demarcating the county's spaces with a well-being deficit. The weighting process increased the indicators for all units, most of them by over 0.6 points. The absolute difference is close to the average (10 points). The real issue is how strongly polarised the districts are, and how rare are mean values approximating the national average.

Pest County cannot be interpreted on its own. Budapest's inclusion always has to be borne in mind with all examined trends in well-being indexes. The proximity of the capital city has a favourable impact on the county. Nevertheless, there are peripheries with indicators falling well (Nagykáta and Nagykőrös districts) or moderately (Dabas Cegléd, Ráckeve and Aszód units) behind the national average here as well. At the other extreme, are regions with higher-than-national average objective well-being indicators(Budakeszi, Dunakeszi, Pilisvörösvár, Szentendre, Gödöllö, Érd and Szigetszentmiklós). These all fare better than Györ's LAU1 area, the "champion of out of the metropolitan areas". The indicators of the seven districts are equal, or even higher, than the capital city, justifying the large-scaled suburbanisation ${ }^{3}$ process around Budapest. These formerLAU1 units, completed with Vác (North) and Ráckeve (South) are small regions forming from the primary influence zone of the capital city. The overweighting of the questionnaire result dimensions did not have a uniform effect: it increases the values of the indicators for a smaller group of regions, triggers no change worth mentioning and decreases the index for approximately one-third. The absolute difference is one of the highest in the counties; the underlying reason for this is the extremely high values of the leading districts rather than the condition of the spaces with a deficit (as their index values are in the mid-third section of the national list).

\section{A few territorial interconnections of the objective well-being model}

The spatial structure under the standard and the weighted models does not differ fundamentally from either that outlined on the basis of the traditional indicators of territorial inequalities or the complex indexes measuring progress and backwardness (Nemes Nagy 1996, Koós et.al. 2006, Csatári 2010, Rechnitzer 2010, Tánczos 2010), or even several other recent approaches (Nagy 2006, Csite-Németh 2007, Garami 2009, MKIK GVI 2013).

The model responds to the characteristics of settlement networks and settlement hierarchy rather sensitively. The existence of large cities and mid-size towns with a number

3 In this case we use the 'classical' definition of suburbanisation, namely, the relative deconcentration of high-class and middle-class inhabitants of the city. 
of functions can raise the well-being index of districts significantly, and owing to the feedthrough effect, their proximity may even affect the index of neighbouring units. Higherlevel well-being indexes benefit outright from a multiple pole settlement hierarchy with strong urban centres. By contrast, the existence of an unbalanced urban structure with few functions affects the indexes adversely (Figure 1 and 2).

The impact of Budapest goes far beyond the city limits, and in some cases, the boundaries of Pest County. Such an indirect effect is rare in the case of other centres (Figure 1 and 2).

Nor can the size of a city or the regional centre role guarantee a high-value well-being indicator. Likewise, the county seat status alone does not automatically mean that cities with this status and their environs are considered as the most prestigious places or spaces in terms of well-being in the county in question (Figure 1 and 2),

Spaces with a well-being deficit are clusters, and in essence, coincide with spaces of backwardness. (Figure 1 and 2) Such concentration suggests that there is/can be strong correlation between the quality of local economies and societies and well-being. In order to test it, a set of interviews needs to be conducted with local actors.

Several dimensions of material wealth are strongly reflected, either directly or indirectly, in the model. The reason for the overweighting of both groups of indicators is that Western literature on post-socialist space emphasises the role that these three dimensions (Table 1) have played in local and personal/private/familial successes after the transition (Stenning et al. 2011).

Compared to the traditional model measuring progress and backwardness, differences were only identified at the level of districts; however, these differences signified no radical change in the position of the district concerned, rather, a shift of one or two categories. As some of the components of well-being take rather long to change, a spectacular transformation of the current spatial structure over the medium term is hardly a likely scenario.

It is important to note that this paper only studied 'objective' well-being indicators as either no data was needed for the study of the dimensions suggested by the Stiglitz-SenFitoussi model, or the data available was not comprehensive. Additionally, the results of the questionnaire survey were indispensable for definitive re-calculations and the reweighting of the model.

\section{REFERENCES}

Commission of the European Communities (2009): GDP and beyond Measuring progress in a changing world, Communique from the EU Commission to the EU Council and the European Parliament, 20/08/2009 COM(2009) 433., Brussels.

Bajmócy, Z.-Lengyel, I.-Málovics, Gy. (2012): Regionális innovációs képesség, versenyképesség és fenntarthatóság JATEPress, Szeged.

Blanchflower, D. G.-Oswald, A. J. (2004): Well-being Over Time in Britain and the USA Journal of Public Economics 88 (7-8): 1359-1386.

Boelhouwer, J.-Stoop, I. (1999): Measuring Well-being in the Netherlands The SCP Index from 1974 to 1997 Social Indicators Research 48 (1): 51-75

Booysen, F. (2002): An overview and evaluation of composite indices of development Social Indicators Research 59 (2): 115-151.

CIW-Canadian Index of Well Being (2012): How are Canadians Really Doing? The 2012 CIW Report. Measuring What Matters, University of Waterloo, Waterloo. 
CIW-Canadian Index of Well Being (2009): First report of the Canadian Index of Wellbeing University of Waterloo, Waterloo.

Constanza, R. et.al. (2009): Beyond GDP: The Need for New Measures of Progress. Pardee Papers No. 4. Boston University Press, Boston

Csatári, B. (2010): Területi egyenlőtlenségek néhány régi-új tényezője a mai Magyarországon In: (Barta Gy.Beluszky, P.-Földi, Zs.-Kovács, K.. eds) A területi kutatások csomópontjai pp. 490-513., MTA RKK, Pécs.

Csite, A.-Németh, N. (2007): Az életminőség területi differenciái Magyarországon: a kistérségi szintű HDI becslési lehetőségei Magyar Tudományos Akadémia Közgazdaságtudományi Intézet, Budapesti Corvinus Egyetem, Emberi Erőforrások Tanszék, Budapest.

Decancq, K-Lugo, M. A. (2010): Weights in multidimensional indices of well-being: an overview Katholike Universiteit Leuven, Public Economics, Center for Economic Studies, Discussions Paper Series (DPS) 10.06, http://feb.kuleuven.be/eng/ew/discussionpapers/Dps10/Dps1006.pdf (downloaded $01.12 .2014)$

Diefenbacher, H.-Zieschank, R. (2008): Wohlfahrtsmessung in Deutschland, Ein Vorschlag für einen neuen Wohlfahrtsindex, F\&E-Studie FKZ 3707 11101/01, http://ec.europa.eu/environment/beyond_gdp/ download/BMU_UBA_Endbericht_v20_endg.pdf (downloaded 01.12.2014)

Diener, E.-Biswas-Diener, R. (2002): Will Money Increase Subjective Well-being? Social Indicators Research 57 (82): 119-169.

Garami, E. (2009): A humán erőforrás területi különbségei. Az emberi fejlődés indexének hazai alkalmazhatósága Területi Statisztika 49 (3): 280-298.

Gébert, J.-Málovics, Gy. - Fáskerti, Zs. (2012): The Limits of Well-Being Measurement at Sub-regional Level. Regional Statistics 2: 45-57.

Koós, B.-Rácz, K.-Neumark, T. (2006): Hátrányos helyzetü térségek társadalmi-gazdasági viszonyai Tér és Társadalom 20 (2): 115-141.

Kovacevic, M. (2010): Review of HDI Critiques and Potential Improvements Human Development Research Paper 33. UNDP, New York

Marks, N. et.al. (2006): The Happy Planet Index New Economic Foundation, London.

Nagy, G. (2006): Gazdasági távolság meghatározása potenciál-modell felhasználásával In: (Kanalas, I.-Kiss, A. eds) A perifériaképzödés típusai és megjelenési formái Magyarországon. pp. 73-86., 111115.MTA RKK ATI, Kecskemét.

NEF-New Economics Foundation (2004): The power and potential of well-being indicators. Measuring young people's well-being in Nottingham. (Economics as if People and the Planet Mattered). The Power of Well-Being, London, UK.

NEF-New Economics Foundation (2012): Measuring Well-being: A Guide for Practitioners Economics as if People and the Planet Mattered, London, UK.

Nemes Nagy, J. (1996): Centrumok és perifériák a piacgazdasági átmenetben Földrajzi Közlemények 44 (1): $31-$ 48.

Németh, Á.-Vercse, T.-Dövényi, Z. (2014): A fejlettség térbeli egyenlőtlenségei Magyarországon az európai uniós csatlakozás után Területi Statisztika 54 (4): 308-332.

OECD Better Life Initiative (2013): OECD Guidelines on Measuring Subjective Well-Being OECD, Washington.

OECD Better Life Initiative (2011): Your Better Life Index - The Complete Dataset with List of indicators and definitions, OECD, Washington.

Rechnitzer, J. (2010): Húsz év múltán - a gazdaság és a társadalom térszerkezetének változásai In: Barta, Gy.Beluszky, P.-Földi, Zs.-Kovács K.. eds) A területi kutatások csomópontjai pp. 317-335., MTA RKK Pécs.

MKIK GVI (2013): Rejtett lakossági jövedelmek kistérségi becslése MKIK Gazdaság és Vállalkozáskutató, Budapest.

Stenning, A.-Smith, A.-Rochovska, A.-Swiatek, D. (2011): Domesticating Neoliberalism. Spaces of Economic Practice and Social Reproduction in Post-socialist Cities Wiley-Blackwell, Oxford.

Stieglitz J.E. (2009): Progress, what progress? OECD Observer No. 272., Washington.

Stieglitz J.E.-Sen A.-Fitoussi J-P. (2009): Report by the Commission on the Measurement of Economic Performance and Social Progress http://www.stiglitz-sen-fitoussi.fr/documents/ rapport anglais.pdf (downloaded 01.12.2014) 
Tánczos, T. (2010): A magyarországi kistérségek jellemzése társadalmi gazdasági fejlettségük és fejlődésük alapján Területi Statisztika 50 (4): 406-419.

The World Bank (2013): Atlas of Global Development 4th Edition., Collins, Washington.

Deutscher Bundestag (2013): WWL - „Wachstum, Wohlstand, Lebensqualität - Wege zu nachhaltigem Wirtschaften und gesellschaftlichem Fortschritt in der Sozialen Marktwirtschaft”, Schlussbericht der Enquete-Kommission, Drucksache 17/13300 http://dipbt.bundestag.de/dip21/btd/17/133/ 1713300.pdf (downloaded 01.12.2014) 
The objective well-being index of Hungarian districts (LAU1 units)

- Unweighted model, 2011

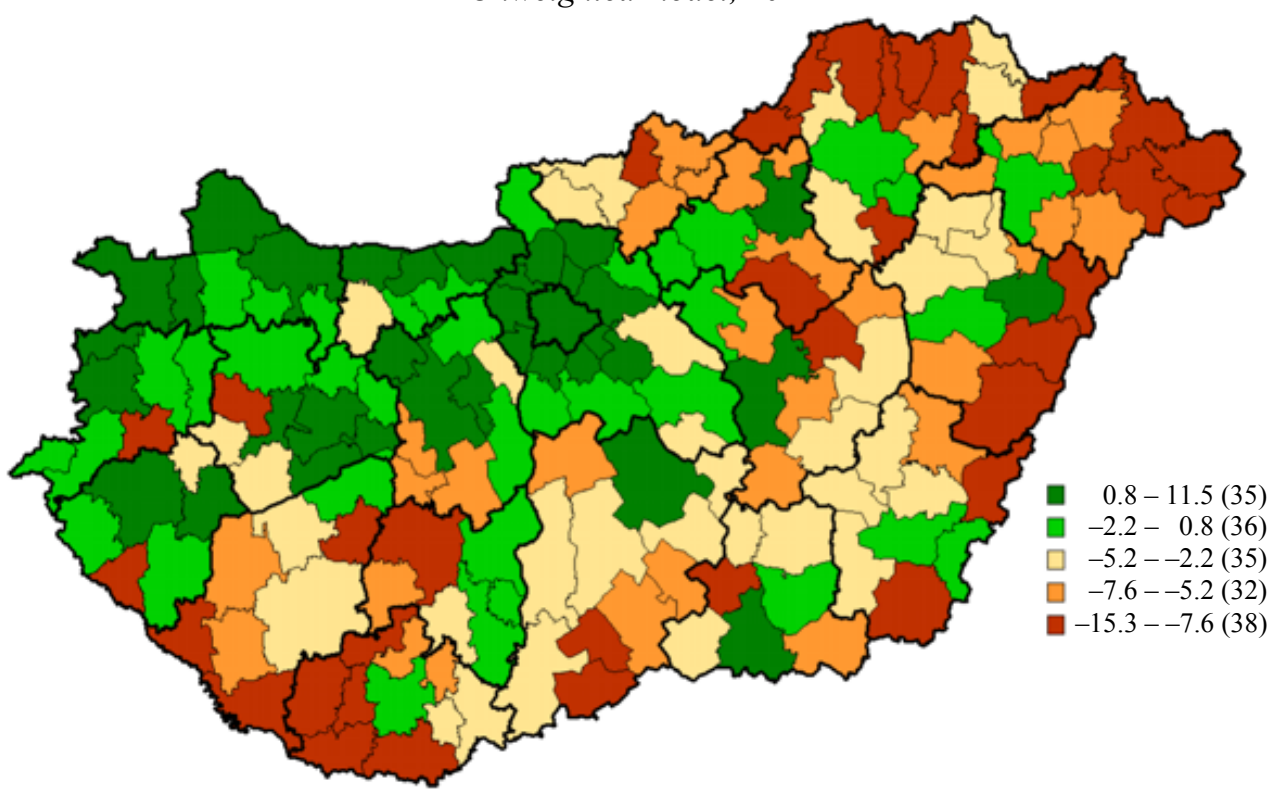

Source: Bálint Koós’ own compilation.

The objective well-being index of Hungarian districts (LAU1 units)

- Weighted model based on the results of questionnaire, 2011

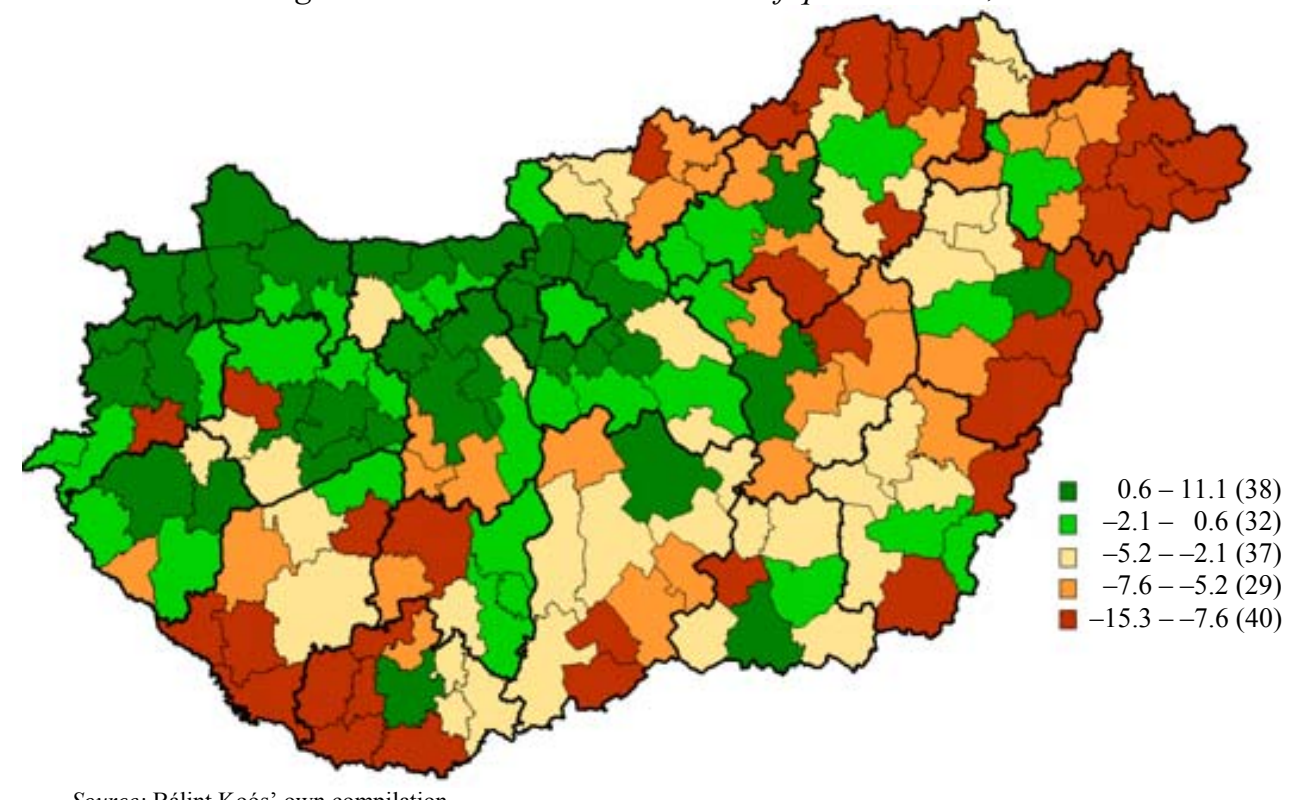

Source: Bálint Koós' own compilation. 